\title{
ENHANCED BIOMEDICAL PROPERTIES OF CHITOSAN-ENOXIL FILMS
}

\author{
GHEORGHE DUCA *, TUDOR LUPAȘCU, ALEXANDRU GONTA, IGOR POVAR, NINA \\ TIMBALIUC, LUCIAN LUPAȘCU
}

Institute of Chemistry, Academy of Sciences of Moldova, Chișinău, Republic of Moldova

*corresponding author: ggduca@gmail.com

Manuscript received: September 2018

\begin{abstract}
Polyphenolic compounds show antioxidant activities by inhibiting the formation of free radicals. Using eco-friendly reactions, which involve oxidation and depolymerization of grape seed tannins, new products for biomedical applications are obtained. Especially, it is of high interest the valorisation of by-products such as grape seeds, which are in considerable quantities in the Republic of Moldova. However, these products are highly labile to environment risk factors. Therefore, the use of polymeric materials, especially by-products such as chitin and chitosan, is a perspective way to design dressing materials such as biomedical films. This paper studies the change of antioxidant activity and bacteria growth inhibition of the synthetized chitosan-Enoxil film. It was demonstrated that the addition of Enoxil to chitosan film in the concentration of 5\% improves antibacterial properties against Bacillus subtilis, Pseudomonas fluorescens and Candida utilis. Moreover, these biofilms have proved an efficient inhibition of the cation ABTS radical (0.42 mg-echiv/mL Tox) and DPPH radical (23.66\% remaining DPPHc). Incorporation of polyphenolic acids to chitosan films could improve the overall lifetime of the food products storage.
\end{abstract}

\section{Rezumat}

Compușii polifenolici manifestă proprietăţi antioxidante prin inhibarea formării radicalilor liberi. Folosind reacții eco-friendly, care implică oxidarea și depolimerizarea taninurilor din semințe de struguri, pot fi obținute produse noi pentru aplicații biomedicale. În special, prezintă interes valorificarea produselor secundare, precum semințele de struguri, care sunt în cantități considerabile în Republica Moldova. Totodată, aceste produse sunt extrem de labile la factorii de risc a mediului ambiant. Prin urmare, utilizarea materialelor polimerice cum ar fi produșii secundari chitina și chitosan, reprezintă o perspectivă de a fabrica biomateriale cum sunt filmele biomedicale. În cadrul acestei lucrări a fost studiată modificarea activitătii antioxidante și antibacteriene a bio-materialelor sintetizate chitosan-Enoxil. S-a stabilit că la adăugarea de Enoxil în filme de chitosan în concentrație de 5\% se îmbunătătesc proprietățile antibacteriene împotriva Bacillus subtilis, Pseudomonas fluorescens și Candida utilis. De asemenea, aceste biofilme sunt eficiente în inhibarea cationului radical ABTS $(0,42 \mathrm{mg}$-echiv/mL Tox $)$ și radicalului DPPH (23,66\%, conc. DPPH remanent). Încorporarea acizilor polifenolici în filme de chitosan ar putea îmbunătăţi durata de viață a produselor alimentare la stocare.

Keywords: tannin, chitosan, biomedical, antioxidant, antibacterial

\section{Introduction}

Winemaking industry is a significant economical branch in the Republic of Moldova, due to the favourable conditions for grapes growing in our country. Climate, water and soil play a key role in the development of this industrial area. Climate conditions and soil fertility are favourable and allow the growing of a vast variety of grapes of high quality. As a result, Moldova has a real potential for exporting the wine products to the European market, but this branch of agro-food industry is accompanied by obtaining large quantities of both liquid and solid waste.

The wine industry in the Republic of Moldova has the potential to process grapes up to 1 million tons/ year by 125 companies, but in recent years only about 550 thousand tons of grapes were purchased and processed. After grapes processing, a significant quantity of wine by-product waste is produced and can be further used. All these products are a source of environmental pollution and create major environmental problems. Therefore, it is important to processes raw material (grapes) using technological lines, which lead to no waste or minimal waste, as well as further processing of secondary wine products in order to obtain a wide range of useful products [1, 2]. Secondary winemaking products are an important source for obtaining special natural products with specific properties that cannot be obtained synthetically, and through their processing allowing a good environmental protection. Waste from the wine industry, consisting mainly from solid and liquid by-products, includes pulp, seeds, yeasts, and may account for an average about $30 \%(\mathrm{w} / \mathrm{w})$ of the grapes used for 
wine production. This waste mostly contains biodegradable organic materials, which can be used to produce various highly demanded products for different industries such as pharmaceutical, cosmetic and food ones. Secondary winemaking products can be processed and the quantities of waste can be significantly reduced by new or modified processing methods, obtaining a variety of products [3].

Some of these wine products contain considerable amounts of polyphenolic components, depending on the type of grapes (white or red), the part of the tissues (hides, seeds, etc.) and processing conditions (e.g. seeds). In recent years, not only secondary byproducts but also a number of other agricultural wastes of vegetable origin have attracted considerable attention as potential sources of bioactive polyphenols, which can be used in the pharmaceutical, cosmetic and food industries. However, in many cases, the adequate feasibility studies on the operation of this agricultural waste are missing.

In recent years, stability and prolonged activity issues of food products have become a growing concern for the food industry. Polymer films using as primary material chitosan are known to be biocompatible, biodegradable, antibacterial, possessing antioxidant activities [4]. Biodegradable films containing active ingredients can effectively maintain food quality and safety, in addition to acting as barriers to moisture and gas [5]. In particular, polyphenolic acids, including gallic acid, grape seed and pomace extract, tea catechins and several hydroxybenzoic acids have been covalently grafted to chitosan or physically incorporated in antioxidant active chitosan films. These modifications benefited the acknowledged protective effects of foods against oxidation reactions [6-11].

The purpose of this paper is to investigate the change of antioxidant activity and bacteria growth inhibition of the synthesized chitosan-Enoxil film in order to improve its antibacterial properties.

\section{Materials and Methods}

\section{Materials}

Chitosan medium molecular weight (mol wt 190,000 $300,000 \mathrm{Da}$ (based on viscosity)), ABTS cation radical 2,2'-azino-bis(3-ethylbenzothiazoline-6-sulphonic acid, DPPH 2,2-diphenyl-1-picrylhydrazyl, luminol, ammonium persulphate, EDTA thylenediamine-tetraacetic acid, Trolox 6-hydroxy-2,5,7,8-tetramethylchroman-2-carboxylic acid were purchased and used from Sigma-Aldrich. $\mathrm{NaOH}, \mathrm{HCl}$, acetic acid, $\mathrm{H}_{2} \mathrm{O}_{2}$ and ethanol were purchased from a local chemicals supplier. Enoxil product was synthesized in our Ecological Chemistry laboratory. Microbiological investigations were performed in collaboration with Moldova's National Public Health Centre (NPHC).
Analysis of antioxidant scavenging properties

Antioxidant scavenging ABTS•+ assay

ABTS cation radical assay is quite often used for the determination of polyphenolic compounds antioxidant activity of polyphenolic compounds, or their complex material with different natural polymers [12]. To control the antioxidant activities of flavonoids, radical ABTS+ was used in this assay, according to the protocol of $\operatorname{Re}$ et al. [13]. For the analysis, a stock solution of cation ABTS $(7 \mathrm{mM})$ was mixed with ammonium persulphate solution $(2.45 \mathrm{mM}$, final volume concentration), and left to stay in dark for $12-16 \mathrm{~h}$ at room temperature. Afterwards, the mixture was transferred to a $70 \%$ ethanol solution in order to obtain a final absorbance of $0.700( \pm 0.02)$, measured at $734 \mathrm{~nm}$. The sample solution was prepared by dissolving $10 \mathrm{mg}$ film into $3 \mathrm{~mL}$ ultra-pure water. Then, adding $40 \mu \mathrm{L}$ sample to $4 \mathrm{~mL}$ of ABTS + solution produces an inhibition of free radicals of $20-80 \%$. The measurement was performed on a Jenway Spectrophotometer 6505, exactly $1 \mathrm{~min}$ after initial mixing. Calibration curve for different Trolox concentrations was drawn, and the result was expressed as $\mathrm{mg}$ echiv/mL Trolox (Figure 1).

\section{Chemilumenescence measurement}

In alkaline solution, $\mathrm{H} 2 \mathrm{O} 2$ is a source of free radicals, as hydroxyl, singlet oxygen and superoxide radicals [14]. These free radicals catalyse the oxidative cleavage of luminol, followed by $\mathrm{N}_{2}$ removal and transition to excited 3-aminophthalate anion form which then deexcite with luminesce as result $[15,16]$. It is known that antioxidant is a powerful radical scavenger that could inhibit the triggering of free radical formation, decreasing the emission of photon light [17]. Therefore, inhibition percentage of free radicals produced in the luminol/Tris-EDTA chemiluminescence generation system after addition of $50 \mu \mathrm{L}$ of aqueous hydrogen peroxide solution $(50 \mu \mathrm{M}), 200 \mu \mathrm{L}$ of Luminol solution $(0.1 \mathrm{mM}), 650 \mu \mathrm{L}$ Tris-EDTA solution ( $\mathrm{pH} \mathrm{8.0)}$ and $100 \mu \mathrm{L}$ aqueous or alcohol solution of sample. The final mixture volume of $1 \mathrm{~mL}$ was vortexed for 10 seconds prior to insertion in the reactor tube. Emitted light was recorded on Promega Glomax Luminometer instrument over $15 \mathrm{sec}$, after initial mixing with peroxide solution. Measurements were performed in triplicates, the fixed value being the arithmetic mean of the parallel analyses.

The antioxidant activity, AA (\%) was calculated according to the following equation:

$$
\mathrm{AA}(\%)=\left(\mathrm{I}_{0}-\mathrm{I}_{\mathrm{S}}\right) / \mathrm{I}_{0} * 100 \%,
$$

where $I_{0}$ and $I_{s}$ are relative light emissions of blank and sample solution after $15 \mathrm{sec}$, respectively.

\section{DPPH radical inhibition assay}

The free radical DPPH ${ }^{*}$ is considered one of the most stable radicals and used for determination of the antioxidant activity [18-20]. In this study, the method described by Wootton-Beard et al. with some minor 
modifications was used. $60 \mu \mathrm{M}$ DPPH in a solution of ethanol in water $(70 \%)$ was prepared before analysis. Its measured absorbance was $0.700 \pm 0.02$ at $517 \mathrm{~nm}$. Prior to analysis, $10 \mathrm{mg}$ of film were immersed in $3 \mathrm{~mL}$ ultra-pure water. In order to measure the radical scavenging activity (\%, remaining DPPH) of biomedical films, $60 \mu \mathrm{L}$ of film forming solution were transferred to $3 \mathrm{~mL}$ of DPPH ethanol solution. After interaction of DPPH free radicals with the antioxidant, the quantity of remaining DPPH was measured. Measurements were performed in triplicates, the fixed value being the arithmetic mean of the parallel analyses.

$$
\% \text { remaining DPPH }=\frac{\text { Abs sample }}{\text { Abs blank }} * 100,
$$

where Abs sample is the sample absorbance measured over $240 \mathrm{~min}$ and Abs blank (DPPH ethanol solution) is the absorbance measured over $240 \mathrm{~min}$.

\section{Microbiological investigation}

Frequently, the microbiological assay for the analysis of the biomedical films is similar to disk applications on inoculated agar plates and incubation at specific conditions with measurement of the inhibition zone surrounding of the disk [21, 22]. Briefly, Petri dishes were sterilized by heating and then, nutrient and Sabouraud Dextrose Agar were poured in aseptic conditions. Moreover, strains of Pseudomonas fluorescens CNMN-PFB-01, Bacillus subtilis CNMN BB-01 and Candida utilis were prepared accordingly to the laboratory procedure, with initial inoculum of $3 \times 10^{8} \mathrm{CFU}$, measured by turbidity method. The microorganisms were diluted in sterilized distilled water to the concentrations of $10^{6} \mathrm{CFU}$. Further, $0.1 \mathrm{~mL}$ of inoculum were taken, representing the seeded dose, put into the centre of the prepared dishes and spread uniformly on the agar plate surface. Subsequently, samples of chitosan and chitosan impregnated with Enoxil (1\%, 2.5\%, and 5\%) films with $20 \mathrm{~mm}$ diameter were immersed in the gelatinous agar. Afterwards, the seeded Petri dishes were placed in the thermostat at $37^{\circ} \mathrm{C}$ for 24 hours. The next day the results of the antimicrobial and antifungal activity were assessed by calculating the diameters of inhibitions around the impregnated discs. All measurements were doubled, the fixed value being the arithmetic mean of the parallel analyses.

Synthesis of chitosan-Enoxil films

The preparation method consists of preparing Enoxil solutions with different concentrations $(1 \%, 2.5 \%$, $5 \%, \mathrm{w} / 1 \mathrm{~g}$ of chitosan) with $2 \%$ (g/100 g of Enoxil solution) chitosan left for 6 hours swelling. Afterwards, concentrated acetic acid was added to obtain a final concentration of $2.5 \%$ in film forming solution. The resulted film forming solution was pipetted on Petri dishes accurately, avoiding the air bubbles, and left to dry at $45^{\circ} \mathrm{C}$ for 24 hours.

\section{Results and Discussion}

\section{Antioxidant activity of the biomedical films}

ABTS free cation radical, being one of the most stable radicals is considered as a first-choice method analysis for the determination of scavenging properties of natural antioxidants. ABTS cation radical method is a universal assay for determination of both hydrophilic and lipophilic compounds [23, 24].

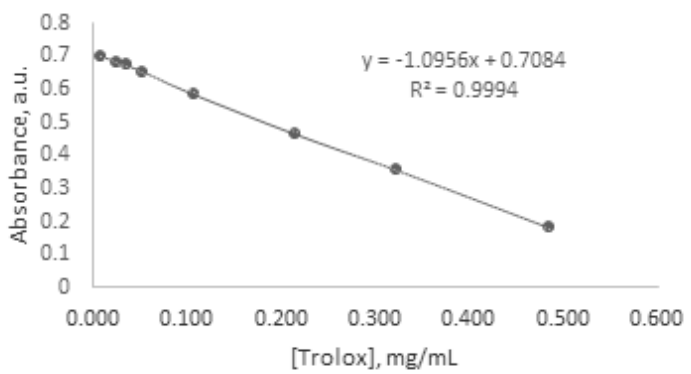

Figure 1.

Trolox calibration curve obtained after inhibition of cation ABTS radical

In this study, chitosan and chitosan-Enoxil films were investigated for antioxidant capacity in free radical scavenging. In order to measure the antioxidant activity of natural inhibitors, a calibration curve for Trolox was plotted (Figure 1). A significant increase in cation ABTS radical scavenging ability was greater for chitosan-film/Enoxil (1\%, 2.5\% and 5\%), as compared to chitosan-film (control). Moreover, chitosanEnoxil $(5.00 \%)$ showed maximum inhibition power (0.42 mg-echiv/mL Trolox, Figure 2), which further illustrated that impregnation of Enoxil antioxidant to chitosan-film increased the antioxidant capacity, by a concentration dependent manner, mainly attributed to the hydrophilic polyphenolic acid components of Enoxil.

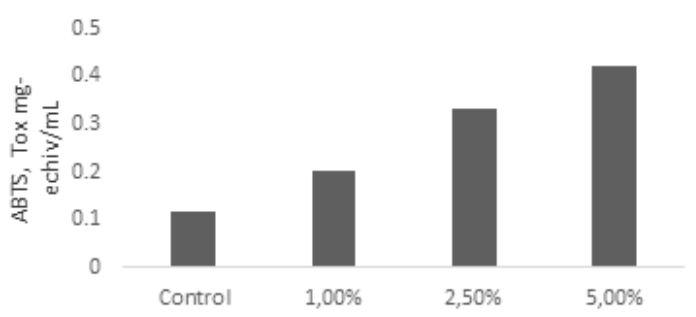

Figure 2.

Radical scavenging ability of chitosan and chitosan-Enoxil film with different concentrations expressed as Eox mg-echiv/mL

Bao et al. [25] Ferreira et al. [26] and others reported similar antioxidant activity. One should mention that chitosan film without Enoxil, possess low inhibition properties of free radicals. Such antioxidant activity of chitosan film has been reported elsewhere [27]. Chemiluminescence assay

The increased or decreased intensity of chemiluminescence signal could be attributed to an oxido-reducing 
process. According to Meghea et al. [28], the increase of the quantum of photons emitted upon molecule transition to a lower energy state means that molecule possess pro-oxidating properties, while the decrease of the chemiluminescence signal corresponds to reducing the properties of the same molecule. As reported by Rolewski et al. [30], quercetin as low as $2 \mu \mathrm{mol} / \mathrm{L}$ exerts pro-oxidant activity. Following these, it is important to identify the efficient concentrations of Enoxil in chitosan film, which determine an antioxidant activity. Therefore, in Table I the results of antioxidant activity, measured by chemiluminescence assay, for chitosan and chitosan-Enoxil films, which exert enhanced antioxidant activity, are presented.

Table I

Determination of antioxidant activity by chemiluminescence assay

\begin{tabular}{|c|c|}
\hline \% of Enoxil in chitosan film & Antioxidant Activity, AA\% \\
\hline Control & 16.2 \\
\hline 1\% Enoxil & 28.9 \\
\hline $2.5 \%$ Enoxil & 45.5 \\
\hline $5 \%$ Enoxil & 79.2 \\
\hline
\end{tabular}

DPPH assay

In order to determine the antioxidant activity of chitosan and chitosan-Enoxil films by using DPPH radical method, kinetic curves plotting absorbance (a.u.) vs time (min) were performed (Figure 3).

For better understanding the efficient inhibition of DPPH radical, a total time interval of 240 min was chosen to measure the absorbance at the steady state. Such an approach was reported by Kedare et al. [31] and Chat et al. [29]. These results, presented in Table II, emphasized that Enoxil showed a fast decrease time evolution followed by a slow antiradical kinetics reaching endpoint at $240 \mathrm{~min}$.

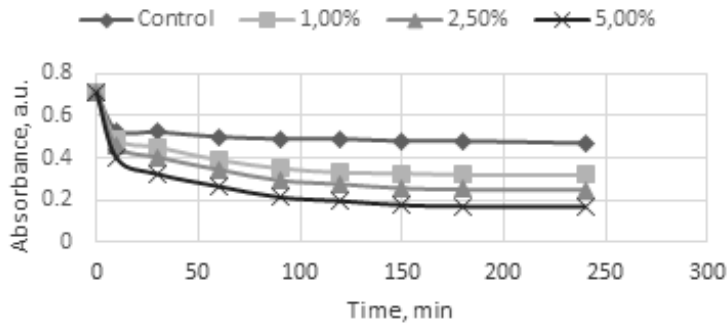

Figure 3.

Inhibition of free DPPH radical by chitosan and chitosan-Enoxil solutions

Table II

Determination of DPPH radical inhibition by antioxidant biomedical films

\begin{tabular}{|l|l|}
\hline$\%$ of Enoxil in chitosan film $\%$ remaining DPPH \\
\hline
\end{tabular}

\begin{tabular}{|c|c|}
\hline Control & 66.83 \\
\hline $1 \%$ Enoxil & 44.71 \\
\hline $2.5 \%$ Enoxil & 34.92 \\
\hline $5 \%$ Enoxil & 23.66 \\
\hline
\end{tabular}

The results (Table II) demonstrate an increase of antioxidant activity by $76 \%$ for Chitosan-Enoxil (5\%). According to the time reactions, the curve denotes the mechanism of fast $\mathrm{H}$-abstraction, followed by a slow and more complex mechanism due to interaction between chitosan and Enoxil [19].

Microbiological investigations

Antimicrobial activity was improved with the addition of Enoxil into chitosan film. Enoxil-chitosan film increases significantly the size diameter around the film inoculated with Pseudomonas fluorescens CNMNPFB-01, Bacillus subtilis CNMN BB-01, compared to control chitosan film after $24 \mathrm{~h}$ at $37^{\circ} \mathrm{C}$ (Figure 4).

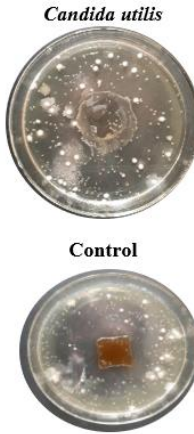

Enoxil 3\%

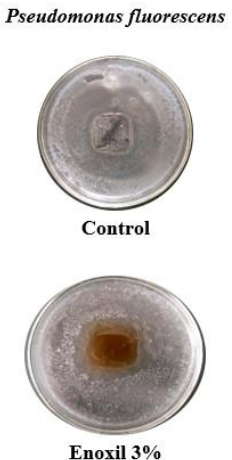

Enoxil 3\%

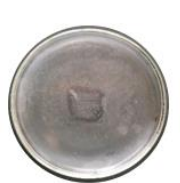

Control

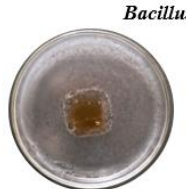

Enoxil 1\%

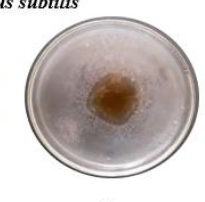

Enoxil 2.5\%

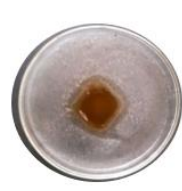

Enoxil 5\%

Figure 4.

Determination of the inhibition zones diameter for Pseudomonas fluorescens CNMN-PFB-01, Bacillus subtilis CNMN BB-01 and Candida utilis after interaction with control and chitosan-Enoxil films 
Inhibition zones for Pseudomonas fluorescens CNMN-PFB-01, Bacillus subtilis CNMN BB-01 and Candida utilis after interaction with chitosan and chitosan-Enoxil films

\begin{tabular}{|c|c|c|c|}
\hline \multirow{2}{*}{ \% of Enoxil in chitosan film } & \multicolumn{3}{|c|}{ Diameter inhibition zones, mm } \\
\cline { 2 - 4 } & Pseudomonas fluorescens & Bacillus subtilis & Candida utilis \\
\hline Control, initial zone & 20 & 20 & 20 \\
\hline 1\% Enoxil & 29 & 26 & 28 \\
\hline 2.5\% Enoxil & 34 & 30 & 32 \\
\hline 5\% Enoxil & 40 & 36 & 42 \\
\hline
\end{tabular}

The antibacterial properties of chitosan edible films incorporated with Enoxil is explained mainly by the presence of polyphenolic acids in the product Enoxil, which interacts with bacteria cell protein by hydrogen bonding though inhibiting bacteria further growth. Moreover, phenolic compounds can damage the bacterial cell membrane, though causing leakage of intracellular constituents. However, chitosan is also known to inhibit positive bacteria growth, where the epithelial cell wall consists of teichoic acid, by ionic interaction between cation form chitosan and anionic nature of teichoic acid. The inhibition zones for Pseudomonas fluorescens CNMN-PFB-01, Bacillus subtilis CNMN BB-01 and Candida utilis after interaction with chitosan and chitosan-Enoxil films are shown in Table III. The best result for inhibiting both gram-positive, gram-negative bacteria and fungus was shown by chitosan-Enoxil 5\% composition film, with the diameter of inhibition zones for Pseudomonas fluorescens (40 mm), Bacillus subtilis $(36 \mathrm{~mm})$ and Candida utilis (42 $\mathrm{mm})$.

\section{Conclusions}

Addition of antioxidant components to chitosan films increases the inhibition of free radicals, thus contributing to new biomedical applications. The order of antioxidant activity measured by DPPH, ABTS and chemiluminescence assay is the following: Cts-Enoxil (5\%) > Cts-Enoxil (2.5\%) > Cts-Enoxil (1\%), which confirms that by increasing the concentration of Enoxil in chitosan film, the scavenging ability of radical sources is improved. Bacteria growth inhibition is growing linearly, by increasing the concentration of Enoxil in the chitosan film. Chitosan film impregnated with 5\% Enoxil showed promising results against both gram-positive and gram-negative bacteria. Films with enhanced antibacterial properties are very important for application in food packaging industry to delay or prevent the growth of microorganisms on the product's surface.

\section{Acknowledgement}

The research leading to these results has received funding from the People Programme (Marie Curie
Actions) of the European Union's Seventh Framework Programme FP7/2007-2013/ under REA grant agreement PIRSES-GA-2013-612484.

\section{References}

1. Teixeira A, Baenas N, Dominguez-Perles R, Barros A, Rosa E, Moreno DA, Garcia-Viguera C, Natural bioactive compounds from winery by-products as health promoters: a review. Int J Mol Sci., 2014; 15: $15638-15678$.

2. Lupascu T, Gonta A, Studies on the antioxidant activity of the compound Enoxil and its related forms. Chem J Mold., 2011; 6(2): 58-64.

3. Makris DP, Boskou G, Andrikopoulos NK, Polyphenolic content and in vitro antioxidant characteristics of wine industry and other agri-food solid waste extracts. Journal of Food Composition and Analysis, 2007; 20: 125-132.

4. Gómez-Estaca J, López de Lacey A, LópezCaballero ME, Gómez-Guillén MC, Montero P, Biodegradable gelatin-chitosan films incorporated with essential oils as antimicrobial agents for fish preservation. Food Microbiol., 2010; 27: 889-896.

5. Cárdenas G, Anaya P, von Plessing C, Rojas C, Sepúlveda J, Chitosan composite films. Biomedical applications. J Mater Sci: Mater Med., 2008; 19: 2397-2405.

6. Lee DS, Woo JY, Ahn CB, Je JY, Chitosanhydroxycinnamic acid conjugates: Preparation, antioxidant and antimicrobial activity. Food Chemistry, 2014; 148: 97-104.

7. Liang J, Li F, Fang Y, Yang W, An X, Zhao L, Xin Z, Cao L, Hu Q, Synthesis, characterization and cytotoxicity studies of chitosan-coated tea polyphenols nanoparticles. Colloids Surf $B$ Biointerfaces, 2011; 82: 297-301.

8. Udeanu DI, Albu Kaya MG, Ghica MV, Marin S, Marin MM, Kaya DA, Popa L, Dinu-Pîrvu C, Antiinflammatory drug-loaded biopolymeric spongious matrices with therapeutic perspectives in burns treatment. Farmacia, 2018; 66(5): 783-790..

9. Sun L, Sun J, Chen L, Niu P, Yang X, Guo Y, Preparation and characterization of chitosan film incorporated with thinned young apple polyphenols as an active packaging material. Carbohydr Polym., 2017; 163: 81-91.

10. Verlee A, Mincke S, Stevens CV, Recent developments in antibacterial and antifungal chitosan and its derivatives. Carbohydr Polym., 2017; 164: 268-283.

11. Liu J, Pu H, Liu S, Kan J, Jin C, Synthesis, characterization, bioactivity and potential 
application of phenolic acid grafted chitosan: A review. Carbohydr Polym., 2017; 174: 999-1017.

12. Erel $\mathrm{O}$, A novel automated direct measurement method for total antioxidant capacity using a new generation, more stable ABTS radical cation. Clin Biochem., 2004; 37: 277-285.

13. Re R, Pellegrini N, Proteggente A, Pannala A, Yang M, Rice-Evans C, Antioxidant activity applying an improved ABTS radical cation decolorization assay. Free Radic Biol Med., 1999; 26: 1231-1237.

14. Bokare AD, Choi W, Review of iron-free Fentonlike systems for activating $\mathrm{H}_{2} \mathrm{O}_{2}$ in advanced oxidation processes. J Hazard Mater., 2014; 275: 121-135.

15. Pham AN, Xing G, Miller CJ, Waite TD, Fentonlike copper redox chemistry revisited: Hydrogen peroxide and superoxide mediation of coppercatalyzed oxidant production. Journal of Catalysis, 2013; 301: 54-64.

16. Whitehead TP, Thorpe GHG, Maxwell SRJ, Enhanced chemiluminescent assay for antioxidant capacity in biological fluids. Analytica Chimica Acta, 1992; 266: 265-277.

17. Triantis T, Stelakis A, Dimotikali D, Papadopoulos $\mathrm{K}$, Investigations on the antioxidant activity of fruit and vegetable aqueous extracts on superoxide radical anion using chemiluminescence techniques. Analytica Chimica Acta, 2005; 536: 101-105.

18. Fadda A, Serra M, Molinu MG, Azara E, Barberis A, Sanna D, Reaction time and DPPH concentration influence antioxidant activity and kinetic parameters of bioactive molecules and plant extracts in the reaction with the DPPH radical. Journal of Food Composition and Analysis, 2014; 35:112-119.

19. Lue B-M, Nielsen NS, Jacobsen C, Hellgren L, Guo Z, Xu X, Antioxidant properties of modified rutin esters by DPPH, reducing power, iron chelation and human low density lipoprotein assays. Food Chemistry, 2010; 123: 221-230.

20. Sharma OP, Bhat TK, DPPH antioxidant assay revisited. Food Chemistry. 2009; 113: 1202-1205.

21. Gómez-Estaca J, López de Lacey A, LópezCaballero ME, Gómez-Guillén MC, Montero P, Biodegradable gelatin-chitosan films incorporated with essential oils as antimicrobial agents for fish preservation. Food Microbiol., 2010; 27: 889-896.
22. Lin S, Chen L, Huang L, Cao S, Luo X, Liu K, Novel antimicrobial chitosan-cellulose composite films bioconjugated with silver nanoparticles. Industrial Crops and Products, 2015; 70: 395-403.

23. Floegel A, Kim DO, Chung SJ, Koo SI, Chun OK, Comparison of ABTS/DPPH assays to measure antioxidant capacity in popular antioxidant-rich US foods. Journal of Food Composition and Analysis, 2011; 24: 1043-1048.

24. Osman AM, Wong KKY, Fernyhough A, ABTS radical-driven oxidation of polyphenols: isolation and structural elucidation of covalent adducts. Biochem Biophys Res Commun., 2006; 346: 321329.

25. Bao S, Xu S, Wang Z, Antioxidant activity and properties of gelatin films incorporated with tea polyphenol-loaded chitosan nanoparticles. $J$ Sci Food Agric., 2009; 89(15): 2692-2700.

26. Ferreira AS, Nunes C, Castro A, Ferreira P, Coimbra MA, Influence of grape pomace extract incorporation on chitosan films properties. Carbohydr Polym., 2014; 113: 490-499.

27. Moradi M, Tajik H, Razavi Rohani SM, Oromiehie AR, Malekinejad H, Aliakbarlu J, Hadian M, Characterization of antioxidant chitosan film incorporated with Zataria multiflora Boiss essential oil and grape seed extract. LWT - Food Science and Technology, 2012; 46: 477-484.

28. Voicescu M, Vasilescu M, Meghea A, Energy transfer from the aminophthalate dianion to fluorescein. Journal of Fluorescence, 2000; 10: 229-229.

29. Chat OA, Najar MH, Dar AA, Evaluation of reduction kinetics of 2, 2-diphenyl-1-picrylhydrazyl radical by flavonoid glycoside rutin in mixed solvent based micellar media. Colloids and Surfaces A: Physicochemical and Engineering Aspects, 2013; 436: 343-353.

30. Rolewski P, Siger A, Nogala-Kałucka M, Polewski $\mathrm{K}$, Evaluation of antioxidant activity of alphatocopherol and quercetin during oxidation of phosphatidylcholine using chemiluminescent detection of lipid hydroperoxides. Pol J Food Nutr Sci., 2009; 59(2): 123-127.

31. Kedare SB, Singh RP, Genesis and development of DPPH method of antioxidant assay. J Food Sci Technol., 2011; 48:412-422. 